\title{
Martin Luther and Musically Expressed Theology
}

\author{
Adam Hough, University of Phoenix
}

\begin{abstract}
This paper seeks a reappraisal of Martin Luther's complex understanding of theology's place in the social and political reformation of $16^{\text {th }}$-century Germany. Here I seek to reintroduce an element of that theology that has been largely absent from mainstream scholarship: music. Building on Robin Leaver's influential 2007 work, Luther's Liturgical Music, wherein he argues that Luther's liturgical song-writing ought to be understood theologically, I will demonstrate how the reformer sought to use a musically expressed theology to build a foundation of faith among the German laity-a prerequisite, he believed, to a successful reformation of Christian religion and society. Luther's answer to the failures of the early evangelical Reformation was an educational programme centred on teaching a theology of the Psalms through music.
\end{abstract}

"And this which has been begun during my lifetime will be completed after my death. St. John Huss prophesied of me when he wrote from his prison in Bohemia, "They will roast a goose now (for 'Huss' means 'a goose'), but after a hundred years they will hear a swan sing, and him they will endure."

-Martin Luther, $1530^{1}$

1 Luther's Works. American Edition, Vol. 34, eds. Jaroslav Pelican and Helmut T. Lehmann, Fortress Press: Philadelphia, 1966. \{Luther's Works to be hereafter referred to as $L W$, followed by volume item and page number. In this case, the citation would read $L W 34: 104\}$. 
"I know and bear true witness that the holy man of God, Luther, the Prophet and Apostle to the German nation, had a great love for music in plainsong and polyphony. Many precious hours have I sung with him, and have often seen how the dear man became so merry and joyful in spirit from singing, that he could hardly become tired and weary of singing and speaking so splendidly about music."

-Johann Walter, c. $1533^{2}$

Historians and scholars of the Reformation are generally in agreement that Martin Luther was favourably disposed towards music. Countless examples can be found to evidence the great comfort and solace he found in the art. "It is the function of music," he writes, "to arouse the sad, sluggish and dull spirit." In his poem dedicated to "Frau Musica" he opens,

Of all the joys upon this earth

None has for men a greater worth

Than what I give with my ringing

And with voices sweetly singing ${ }^{4}$

Where academic consensus waivers, though, is in Luther's attitudes towards music with respect to reformation. The prevailing historiographical tradition pays little respect to music as anything more than a devotional aid. Within this tradition, we typically find music treated together with Luther's liturgical reforms. Even here, however, the liturgical function of music is viewed as somewhat superficial and undefined. In both the Oxford Encyclopedia of the Reformation $(1996)^{5}$ and the Cambridge Companion to Martin Luther

2 Walter's reflections on Luther were included in Praetorius' 1612

Leiturgodia Sionia Latina. The above quotation is believed to have been originally written by Walter in the early 1530s. For greater detail see Robin Leaver's analysis, "Johann Walter on Luther" in Luther's Liturgical Music:

Principles and Implications. (Grand Rapids: Wm. B. Eerdmans Publishing

Co., 2007), 333.

3 LW 10:43.

$4 L W$ 53:319.

5 See Bartlett R. Butler, "Hymns," in The Oxford Encyclopedia of the Reformation. ed. Hans J. Hillerbrand. (Oxford University Press, 1996, 2005). 


\section{Martin Luther and Musically \\ Expressed Theology}

(2003), ${ }^{6}$ Luther's hymnody is treated as no more than a devotional product of his theology. In many treatments, the theological meaning and significance of Luther's music is overshadowed, if not entirely overlooked. In these works, the social-cultural impact of Luther's music, particularly his interest in congregational singing, greatly outweighs more theologically minded interpretations. Given the immense influence of Robert Scribner and Peter Burke on Reformation historiography over the past forty years, this is not altogether surprising. As they demonstrated, the ability to mobilize a variety of media in service to the evangelical cause was undoubtedly central to the quick spread of Protestant thought and culture in the first half of the $16^{\text {th }}$ Century. ${ }^{7}$ Along with illustrative woodcuts and vernacular Flugschriften, music has as often as not found itself more at home in the cultural history of the Reformation. With respect to Luther's music as a tool of the Reformation, therefore, there has been much to say about Luther and music.

Criticisms of Luther's reformation efforts are in no short supply. Many have argued that there was actually very little originality in Luther's reforms, and he is often charged with being a 'cut-andpaste' reformer. ${ }^{8}$ Bartlett Butler, for example, writes in the Oxford Encyclopedia that, "Luther was unconcerned with innovation or originality," adding, "On the contrary, his work was extraordinarily conservative, borrowing from the past and adapting it to the present" Joyce Irwin suggests further that as far as advancing the liturgical

6 This dismissal of music can be seen, for example, in The Cambridge Companion to Martin Luther. ed. Donald. K. McKim. Cambridge: Cambridge UP, 2003), 12-15. The Cambridge Companion has been reviewed by both Leaver and Timothy J. Wengert. Both have criticised its unevenness and oversimplification, especially with regard to its entries' attention to Luther's music. Leaver, 2007, 1-2; Timothy J. Wengert, "Review Essay: The Cambridge Luther, an Unreliable Companion," Lutheran Quarterly. Vol. 19 (2005): 79-84.

7 R. W. Scribner, For The Sake of Simple Folk: Popular Propaganda for the German Reformation. (Oxford: Clarendon Press, 2004), xxv-xxix; see also Peter Burke, Popular Culture in Early Modern Europe. $3^{\text {rd }}$ edition. (Burlington: Ashgate, 2009).

8 See Leaver's "Musical Hermeneutics in Luther's Liturgical Reforms" for a critical historiography of Luther's reform efforts, as well as Leaver's refutation of them. Leaver, 173-190.

9 Butler, "Hymns" The Oxford Encyclopedia of the Reformation. 
function of music was concerned, Luther was no more than a prelude to Thomas Müntzer. ${ }^{10}$ In his 2005 work, Worship Wars in Early Lutheranism: Choir, Congregation and Three Centuries of Conflict, Josef Herl makes the argument that Luther was uninterested in dramatically reforming the function and meaning of religious music. In support of this argument, Herl uses early Lutheran liturgical orders and visitation reports to deconstruct commonly held perceptions that ascribe any revolutionary quality to musical reform in the Lutheran church service. ${ }^{11}$

One argument common to many of these critical examinations of music in Luther's reformation focuses on the proportionality of musical references in the Reformer's voluminous writings. Compared to his scriptural interpretation or his treatises concerning secular authority, which each themselves can easily span several volumes, the entirety of his writings on music would not likely fill even one. Regarding music as but a percentage of the whole is problematic though. Music, for Luther, was not simply a by-product of his ostensibly more theologically substantial reforms. His attitude towards music in the early 1520's serves in fact as an example par excellence of what he was trying to accomplish with his overall theological and, by extension, political and social reformation. He was setting out to excise all pretences to temporal authority from the governance of the spiritual kingdom. This exercise, however, was a corollary of a more fundamentally important concern for Luther. Not only was

10 Joyce Irwin, Neither Voice nor Heart Alone: German Lutheran Theology of Music in the Age of the Baroque. (New York: Lang, 1993), 1-7.

11 Herl's overall argument is that the traditionally accepted narrative that there was a dramatic shift to a vernacular, congregation-dominated musical liturgy in $16^{\text {th }}$-century Lutheran churches is unsubstantiated. He argues that in fact the chorus retained its musical-liturgical responsibilities long after Luther died. He argues further that scholars have overestimated Luther's enthusiasm for congregational singing, and that Luther was actually much more conservative with respect to musical reforms. He analyzes a number of $16^{\text {th }}$ - and $17^{\text {th }}$-century liturgical orders to demonstrate that supposedly few churches were quick to adopt either the vernacular liturgy or the practice of congregational singing. Using visitation records from about $1527-8$ to the middle of the $17^{\text {th }}$-Century, he traces a number of trends in Lutheran churches. Of theses, the most important for our purpose is that visitors seemed particularly interested in the quality of congregational singing in the parishes they visited, and that this singing was often judged to be of a poor quality. 
Luther trying to develop a comprehensive evangelical theology- an essential character of which is spirit-law dialectic- but he was also developing a concurrent philosophy related to the meaning and forms of theological expression.

His experimentation with musically expressed theology was therefore informed by the same concerns that drove Luther to develop his ideas about the Two Kingdoms and to articulate his Christian hermeneutics in light of an often hostile political-religious context. Theologically, he had the tricky task of transferring Christian authority from the Church to the Gospel, a task made trickier still by the fact that the exercise would be in vain should the facilitation of that transference ever become dependent on human authority to sustain it. In other words, the Word of God would become meaningless if, through secular influences, it took on the character of Law. So, while works like On Temporal Authority and Avoiding the Doctrines of Men do not explicitly promote the idea of musically expressed theology, these works, in criticizing the inherently legal, and therefore secular, nature of man-made doctrines and decrees, were important antecedents to Luther's development of a musically expressed theology. Where music is not explicitly referenced, the desire for a reappraisal of Christian authority, and perhaps more importantly the expression thereof, is nonetheless ubiquitous. The role Luther developed for music was born from his desire to create educational and liturgical reforms consonant with his evangelical theology, without, of course, compromising the fundamentally spiritual message through subordination to human laws or doctrines. We therefore ought to view Luther's references to the role and nature of music as an ongoing organic development within Luther's broader theology, neither external to it nor simply a watered-down reflection of it.

A second criticism of those who claim music was not an integral part of Luther's reformation follows from the charge that these historians have engaged in selective citation, thereby presenting a skewed interpretation of this relationship. Josef Herl, for example, cites Luther on a number of occasions apparently complaining about music, and he is not entirely wrong to do so. In fact, in the introduction to his 2007 book Luther's Liturgical Music: Principles and Implications, Robin Leaver collects no less than eight significant 
passages that show Luther to be critical of music, ${ }^{12}$ and still more could be added to that list. ${ }^{13}$ As Leaver is quick to point out, however, Luther is not critical of music, but rather of the way music had been and continued to be used in the Christian service. In one instance Luther writes, "Therefore let the works go, no matter how great they may be, prayers, chants, yammering, and yapping; for it is certain that nobody will ever get to God through all these things." ${ }^{14}$ In this case, Luther is railing against the notion that singing hymns and songs is interpreted as a good work, and therefore pleasing to God. In another passage, this time from the Formula Missae, Luther warns, "But we must take care - as I have elsewhere explained $-{ }^{15}$ lest the people sing only with their lips, like sounding pipes or harps [I Cor. 14:7]."16 As with the previous example, this passage demonstrates that Luther did not want the singing of religious songs to be a chore. He did not want parishioners singing his songs as if they were simply going through the prescribed motions.

Despite his appreciation of the art, Luther's suspicion of music is perfectly understandable in the context of his Augustinian background and education. In his Confessions, St. Augustine himself struggled

\section{Leaver, 6-8.}

13 In the preface to George Rhau's Symphoniae iucundae, Luther expresses his frustration that music continues to be used impiously: "Take special care to shun perverted minds who prostitute this lovely gift of nature and art [music] with their erotic rantings; and be quite assured that none but the devil goads them on to defy their very nature which would and should praise God its maker with this gift, so that these bastards purloin the gift of God, the enemy of nature and of this lovely art." $L W$ 53:324. See also notes 14 and 15 below.

$14 L W 51: 47$.

15 Here Luther is referencing Concerning the Order of Public Worship, wherein he writes, "Let everything be done so that the Word may have free course instead of the prattling and rattling that has been the rule up to now. We can spare everything but the Word." LW 53:14. Concerning music, this early work (written at the beginning of 1523) is important because it ascribes an equal importance to singing and the reading of scripture within the church service. Both practices, Luther argues, are meaningless unless they are understood to be unconditional, undeserved gifts from God, rather than as a means of pleasing Him. "First, God's Word has been silenced, and only reading and singing remain in the churches. This is the worst abuse." Ibid., 11.

16 Ibid., 38. 


\section{Martin Luther and Musically \\ Expressed Theology}

with the question of music's place in Christian worship. ${ }^{17}$ As with Luther, Augustine recognized the affective potential of music, though he remained suspicious of man's ability to appreciate the difference between music as a form of worship and as a form of indulgence. Nonetheless, Luther, optimistic as he was in the early twenties, was increasingly convinced that music was a gift from God. ${ }^{18}$ Though he would not develop this notion theologically until sometime later, we see this idea already in his preface to the 1524 Walter Hymnal, wherein he exhorts Christians to compose Christian songs "if God has given him like or greater gifts". ${ }^{19}$ We will return to this notion of music's divine origin in short order, but what ought to be noted at present is that although Luther recognized and was indeed concerned about the possibility that his hymns could be used impiously, the rewards to be had from pairing theology with music far outweighed the dangers.

Regardless of whether one recited scripture right from the Gospel or sang Luther's hymns aloud, they were still proclaiming the same Word of God. ${ }^{20}$ How and why songs were sung within the liturgy, therefore, was of great interest to Luther. So, while Luther recognized the possibility that song alone could not make a Christian of a heathen; we should in no way allow these specific criticisms of song's use to undermine our understanding of his enthusiasm for and appreciation of the medium.

17 Augustine writes, "Notwithstanding, when I call to mind the tears I shed at the songs of Your Church, at the outset of my recovered faith, and how even now I am moved not by the singing but by what is sung, when they are sung with a clear and skillfully modulated voice, I then acknowledge the great utility of this custom. Thus vacillate I between dangerous pleasure and tried soundness; being inclined rather (though I pronounce no irrevocable opinion upon the subject) to approve of the use of singing in the church, that so by the delights of the ear the weaker minds may be stimulated to a devotional frame. Yet when it happens to me to be more moved by the singing than by what is sung, I confess myself to have sinned criminally, and then I would rather not have heard the singing." Augustine, Confessions. 10:33 no. 50.

18 In his lectures on Isaiah 16:62, Luther writes "Musica donum dei est"music is a gift from God. WA (Weimar Ausgabe [Luther's collected works in German]) TR no.3815.

19 LW 53:316.

20 See Luther's 1521 A Brief Instruction on What to Look for and Expect in the Gospel. LW 35:117-124. 
Music next to Theology

In perhaps Lutheranism's most formative year, 1530 and the diet of Augsburg, Luther found himself in Cobourg castle in Saxony. Because he was still under the threat of the ban, Luther was prevented from being present at the Augsburg deliberations. He was, however, still able to work, and in fact his time at Cobourg was one of his most productive. Among the projects Luther set out for himself during this period was a comprehensive treatise on music. Along with his promised treatise on the doctrine of justification, this treatise was never actually written; unlike the promised work on justification though, Luther did at least work out an outline of what this treatise would look like. Robin Leaver translates the outline as follows:

I love music.

Its censure by fanatics does not please me

For

1. [Music] is a gift of God and not of man

2. For it creates joyful hearts

3. For it drives away the devil

4. For it creates innocent delights, destroying wrath, unchastity, and other excesses.

I place music next to theology.

This is well known from the example of

David and all the prophets, who all

produced poetry and songs.

5. For [music] reigns in times of peace.

It will be difficult to keep this delightful skill after us.

The Dukes of Bavaria are to be praised in this, that they honour music.

Among our Saxon [Dukes] weapons and cannons are esteemed. $^{21}$

The first point to take from this is that Luther considered music a gift from God, which meant it therefore had divine origins. In 1528, in his sermon on Isaiah 5:11, Luther writes, "Musica donum dei est"-

21 English translation in Leaver, 86; German translation in WA 30 (II) :695; original Latin/Greek version in WA 30(II): 696. 


\section{Martin Luther and Musically \\ Expressed Theology}

music is a gift from God.2 This idea though, was actually not in and of itself new. The anonymous author of the medieval treatise on the quadrivium, the Scholia enchiriadis, wrote sometime in the $9^{\text {th }}$ or $10^{\text {th }}$ Century that:

These four disciplines [arithmetic, geometry, music and astronomy] are not of human devising, but are investigations, such as they are, of divine works; and they lead noble minds, by wonderful arguments, to a better understanding of the work of creation..$^{23}$ [emphasis added]

Where Luther parted from this idea is in the relative importance of each discipline. Music, for Luther, far surpassed its counterparts within the quadrivium. While all four could be considered divine gifts, only one- music- had been used by the prophets and apostles to spread the Word of God. By way of proof, Luther writes,

The devil, the creator of saddening cares and disquieting worries, takes flight at the sound of music almost as he takes flight at the word of theology. This is the reason why the prophets did not make use of any art except music. ${ }^{24}$

The idea that music was a divine gift and not a human invention is developed further in Luther's lectures on Genesis. Lecturing on Genesis 2:24, Luther comments,

If Adam had continued in his innocence, the children that were born would have married. Then, after leaving the table and dwelling place of their parents, they would have had their own trees under which they would have lived separately from their parents. At times they would have come to their father Adam and sing a hymn and praise God, and then they would

22 LW 16:62, WA TR no. 3815.

23 Piero Weiss and Richard Taruskin, eds., Music in the Western World: A History in Documents. (New York: Schirmer, 1984), 39; ed. Martin Gerbert, Scriptores ecclesiastici de musica sacra potissimum. (St. Blaise: Typis SanBlasianis, 1784; and Hildesheim: Olms, 1963), 1:193. Cited in Leaver, 373, note 5 .

24 Letter to Ludwig Senfl, October 1530. LW 49:428. 
have returned to their own homes. ${ }^{25}$

Among the descendants of Abel, singing remained a pure form of worship to God. The descendants of Cain, wishing to imitate their cousins' worship of God, created musical instruments. Though the Cainites' worship was misguided, the effort to mimic their cousins' worship demonstrated a heartfelt desire to return to the true church. Accordingly, Luther writes, "Nevertheless, I believe that there were some among [the children of Cain] who went over to the true church and adopted Adam's faith." ${ }^{26}$ This tells us that not only was song a pure form of worship that could be traced back to before the Fall, but elements of human creativity, in this case musical accompaniment, could actually be integrated into the worship of the true church. As with music itself, so too was the discipline of music-making considered a divine gift. This conclusion is supported by Dietrich Bartel, who writes, "Luther was not willing to abstract the art from the material. Both music and its associated discipline were Godgiven gifts." ${ }^{27}$ What these reclaimed Cainites brought with them was not the music itself, but their fervent desire to find a way to embrace and celebrate the Holy Spirit. By virtue of this desire, the music they brought with them to the church, both the instruments and the concept of musically accompanied song, took on a spiritual quality. "The tongue," explained Luther, "as a tongue, doesn't contribute to faith, and yet it serves faith when the heart is illuminated." 28

Another concept central to Luther's musical theology was the idea that music was 'next to theology'. What does this mean? In the preface to the Symphoniae iucundae, Luther writes, "Ich gebe nach der Theologia der Music den nähesten Locum und höchste Ehre," translated as, "next to the Word of God, music deserves the

$25 L W$ 1:138. Genesis 2:24 reads, "Therefore shall a man leave his father and mother, and shall cleave unto his wife: and they shall be one flesh." $26 L W$ 1:137-138; See Leaver on the relationship between biblical song and music, Leaver, 66-70.

27 Bartel here cites a number of hymnal prefaces Luther wrote wherein he exhorts readers to compose their own Christian hymns if God has given them the talent. The first he cites is the Walter, or Wittenberg Hymnal, and the second is the preface to George Rhau's Symphoniae iucundae: LW 53: 316, 321; in Dietrich Bartel, Musica Poetica: Musical-Rhetorical Figures in German Baroque Music. (University of Nebraska Press, 1997), 3-4.

$28 L W$ 54:71 TR no. 439. 


\section{Martin Luther and Musically \\ Expressed Theology}

highest praise."29 Is music a close second to theology, or is it of equal importance in Luther's valuation? Consider the following passage from a letter written by Luther to Ludwig Senfl in 1530:

Indeed I plainly judge, and do not hesitate to affirm, that except for theology there is no art that could be put on the same level with music, since except for theology [music] alone produces what otherwise only theology can do, namely, a calm and joyful disposition.

So far, this seems to affirm the conclusion that music and theology are on the same level. Both pursuits have a similar spiritual effect, if not also function. The passage continues, however:

Manifest proof [of this is the fact] that the devil, the creator of saddening cares and disquieting worries, takes flight at the sound of music almost as he takes flight at the word of theology. This is the reason why the prophets did not make use of any art except music; when setting forth their theology they did it not as geometry, not as arithmetic, not as astronomy, but as music, so that they held theology and music most tightly connected, and proclaimed truth through Psalms and songs. ${ }^{30}$ (emphasis added)

What we can take from the presence of the word 'almost' is that Luther maintained the distinction between music and theology, but was nonetheless insistent that they were both fundamental to understanding and teaching the Gospel. Music was the medium par excellence of this instruction. Not only was music able to proclaim the Word of God in a form consistent with spiritual, rather than legal

29 In German, see WA 50:370. For the standard English translation, see $L W$ 53:323: "Experience confirms, namely, that next to the Word of God, music deserves the highest praise...the Holy Ghost himself honours [music] as an instrument for his proper work when in his Holy Scriptures he asserts that through [music] his gifts were instilled in the prophets, namely, the inclination to all virtues, as can be seen in Elisha [II Kings 3:15]. On the other hand, she serves to cast out Satan, the instigator of all sins, as is shown in Saul, the king of Israel [I Sam. 16:23]."

$30 L W$ 49:428 
norms, but it was also able to inspire the emotional profundity and sincerity required to both understand and appreciate the meaning of the Gospel, of Christ, and of God's gift to humanity. Luther writes,

We want the beautiful art of music to be properly used to serve her dear Creator and his Christians. He is thereby praised and honoured and we are made better and stronger in faith when his holy Word is impressed on our hearts by sweet music. ${ }^{31}$

'Theology' represented the effort to divine the Word of God through the study of scripture; however, "True theology," explained Luther, "is practical, and its foundation is Christ, whose death is appropriated to us through faith." ${ }^{32}$ To this he adds, "There is only one article and one rule of theology, and this is true faith or trust in Christ." ${ }^{33}$ Luther ascribed to his hymns two functions. For one, Luther's hymns attempted to capture, explain, and proclaim the meaning of the Psalms. Like theology, these hymns interrogated scripture to understand the fundamental truths of the Christian faith. Whereas Christian theology, properly speaking, encompassed the entirety of scripture, including both Old and New Testaments, Luther's hymns generally focussed on a specific selection, namely the Psalms. ${ }^{34}$ With respect to the versification of Psalms, song could have the same spiritual role as theology, without confusing the distinctiveness of each. I use the phrase musically expressed theology to describe the functional overlap between music and theology. Luther's hymns were both proselytic and exegetical. Here, the acts of understanding and proclaiming scripture unite with music's powerful affective quality. This overlap then leads to the second purpose of Luther's hymns: to move a person to an emotional state conducive to truly appreciating the

$31 L W 53: 328$

32 LW 54:22 TR no. 153

33 LW 54:157 TR no. 1583

34 While the majority of Luther's hymns were derived from the Psalms, Luther also wrote two hymns on the Ten Commandments, one on the Trinity, and one on the Christian Creed. As will be argued in the following chapter, the subject material of Luther's Small Catechism had already earlier been expressed in his hymns. In fact, in the way they were taught, they were essentially already in a catechetical form. Probably the best recent analysis of Luther's musical catechesis belongs to Leaver in Part II of Luther's Liturgical Music- "Musical Catechesis," 106-169. 


\section{Martin Luther and Musically \\ Expressed Theology}

Gospel; or, in other words, to receive the Holy Spirit. Understanding the Gospel was, after all, a two-dimensional process. Recall that one had to sing "with both the spirit and the mind." ${ }^{35}$ Unlocking the gift of the Word required both an intellectual and emotional investment.

Musicologist Dietrich Bartel was among the first to appreciate the theological importance of music for Luther. He refers to Luther's understanding of music as a "theocentric philosophy of music."36 Music, writes Bartel, was "theology's handmaid...tasked with the role of praising God and edifying humanity." ${ }^{37}$ To this he also adds a didactic quality, whereby Luther used music to teach theology. Referring to Luther's many comments on the metaphysical properties of music, Bartel recognizes that Luther believed music could make the invisible visible, in this case, that music could be recognized as a manifestation of God's benevolent nature. All this though, and Bartel still refers to music as theology's handmaid? What is theology, if not an effort to get to know God? Bartel's interpretation seems to presuppose that theology is a strictly intellectual enterprise. But, as Luther consistently points out, and as even Bartel recognizes, song and music interrogated and made known not only the textual presence of God on earth, but also the metaphysical presence. Consider Luther's interpretation of the sacraments. His entry on baptism in the small catechism reads:

What is Baptism?

Answer: Baptism is not merely water, but it is water used according to God's command and connected with God's Word.

How can water produce such effects?

Answer: It is not the water that produces these effects, but the Word of God connected with the water, and our faith which relies on the Word of God connected with the water. For without the Word of God the water is merely water and no Baptism. ${ }^{38}$

35 See note 37 below.

36 Bartel, 3.

37 Ibid., 6-9.

38 BC, 348-9. 
Likewise on the sacrament of the altar, Luther writes:

How can bodily eating and drinking produce such great effects? (forgiveness of sins, life, and salvation)

Answer: The eating and drinking do not in themselves produce them, but the words "for you" and "for the forgiveness of sin." These words, when accompanied by the bodily eating and drinking, are the chief thing in the sacrament, and he who believes these words has what they say and declare: the forgiveness of sins. ${ }^{39}$

In both these rituals, the action itself is nothing. It is only when the significance of the action is understood with respect to the Gospel that the action takes on a metaphysical, spiritual quality. Luther explains, "Baptism is no more than water, but the water has been surrounded by the Word." 40 The only way to obtain an understanding of the Word is through Faith; Faith of course being only attainable as a gift from God. In the Exhortation, Luther writes of the sacrament of baptism, "The Word...merits more regard than the whole sacrament with all that it is and can do, for the Word is the chief thing." ${ }^{41}$ As with the sacraments, so with scripture. Scripture contained the words of God, but only when it was infused with the Holy Spirit did it become the Word of God- the truth conveyed by the words, made clear by faith. How did one engender this union of Spirit and word? One sang the

39 Ibid., 351-2.

40 LW 54:55 TR no. 365. One should note as well that the Word of God affects the baptismal water only in the context of the sacrament of baptism. The sacrament is truly spiritual only when the act of baptism is attended by faith in the Word and faith in the Word's ability to instil in the water a spiritual quality. The act, the water, Faith, and the Word all have to be present for the sacrament to have meaning. This is why Luther rejected the idea that water itself could be blessed independent of the sacrament. Understanding the spiritual quality of baptismal water as a gift from God was one thing; believing that one could instil the word of God in otherwise regular water and make it something more than natural was sorcery. $L W$ 54:244 TR 3610.

41 The Book of Concord: Confessions of Evangelical Lutheran Church. eds. Robert Kolb and Timothy J, Wengert; trans. Charles Arand...[et al.]. (Augsburg Fortress: Minneapolis, 2000), 82. \{Book of Concord hereafter referred to as $B C\}$. 


\section{Martin Luther and Musically \\ Expressed Theology}

Gospel. As noted above, music itself was a gift from God, as Christ had been- different only in proportion rather than character. Not only was song an inherently divine medium in the sense that it conveyed a message, but it acted also as a conduit to the Holy Spirit.

\section{A brief examination of Luther's hymns}

It is clear that Luther intended that his songs would take on a theological function. What form of Christian theology did Luther attempt to propagate in these songs though? To treat each of his songs in turn is beyond the scope of this discussion. What I offer instead is a concise summary and analysis of his hymns. I should clarify that I use the term 'hymn' here in its broader sense to mean a song of praise or worship, regardless of whether it was to be sung by choir or congregation, or some combination thereof.

In Ulrich Leupold's introduction to Luther's hymns, in the translated collection of Luther's Works, he divides the Reformer's songs into a number of liturgical and topical categories. First, there are those that have a clear role to play in the regular liturgical round. "Now Let Us Pray to the Holy Ghost" is clearly intended to be sung as the introit, just as "In One True God We All Believe" is obviously Luther's rendition of the Creed. The place of these songs is not novel. In most cases Luther's songs here were vernacular versifications of existing Latin songs. As we have seen though, what changed was that the songs could be understood now by all. I do not mean they could be understood simply by virtue of the fact that they were sung in German rather than Latin, though this is important. Instead, I argue that singing the songs themselves helped parishioners access the meaning of the lyrics in a way that previously had been impossible. Singing was supposed to facilitate an emotional investment that deciphered the textual message.

Within Luther's liturgical orders, it was not always explicitly stated which song was to be sung on which occasion, though often Luther makes recommendations. During the administration of the Host, for example, Luther suggests that the hymn "Let God Be Blest" could be sung, or perhaps John Huss' "Jesus Christ, Our God and Saviour." According to regional preferences, liturgical orders could vary on

$42 L W 53: 81-2$. 
which of Luther's songs best captured the needs of each liturgical rite. As indicated earlier, quite often songs would be sung at intervals within the order where Luther does not actually call for singing, most notably immediately before and after the sermon. This gave adventuresome ministers the opportunity for greater versatility when it came to meeting the changing needs of the congregation. What is clear though is that within each liturgical order, a set of core songs are set aside for regular use in the service.

Likewise, many of Luther's other songs also came to be associated with specific Christian rites and traditions outside the Sunday service. Take Luther's deeply personal early hymn, "From Deep Trouble I Cry to Thee", which quickly became a popular standard in Lutheran funeral services. It begins with a desperate plea to God for aid, and then describes how the petitioner finds comfort and hope in God and his Word. The third stanza demonstrates especially well why this song was likely such a great source of solace:

Hope therefore in my God will I,

On my deserts not founding;

Upon him shall my heart rely,

All on his goodness grounding.

What his true Word doth promise me,

My comfort shall and refuge be;

That will I always wait for. ${ }^{43}$

Rather than relying on platitudes to comfort the grief stricken, this song consciously reminds listeners of the theological tenets of Lutheranism that make the passage from life to death such an important and necessary occurrence. The preceding stanza, which deals specifically with the doctrine of justification, seems out of place until we remember the centrality of justification throughout Lutheran theology. It begins, "With thee counts nothing but thy grace/ To cover all our failing." If one understood the doctrine of justification, then one would not be plagued with doubts over whether or not their loved one had satisfied their quota of good works in their lifetime. The comfort here comes not solely from the communal act of worship, but from the theological message imbedded in the worship. The

43 Ibid., 223-4. 


\section{Martin Luther and Musically \\ Expressed Theology}

more gentle funeral hymn, "In Peace and Joy I Now Depart" seems to employ platitude rather than this kind of outright theology; however even here comfort necessitates understanding the sacrifice of Christ and the meaning of the Gospel. The soul of the departed is welcomed into heaven "Through thy precious wholesome word." ${ }^{4}$

Like those songs which fell into use at funerals and weddings, so too did Luther write many other hymns with particular Christian celebrations and feasts in mind. Again, most of these hymns were patterned on existing Latin chants. It should be noted though that the theology Luther taught in these hymns was not necessarily evangelical theology, but quite often more general Christian theology. For Christmas, Luther's songs tend to concern themselves with the Virgin birth and the Trinitarian nature of the Christ-child. The Easter hymn, "Death Held Our Lord in Prison", not only explains the resurrection, but the significance and reasons for the Easter feast. ${ }^{45}$ While the generality of this theological teaching may have contributed to the charge that there was very little originality in Luther's reforms, we should not be quick to assume that $16^{\text {th }}$-century Europeans possessed religious understanding in any great depth. Illiteracy at this time was nearly universal in all but the aristocratic or otherwise educated urban middle class. Church services were still predominantly delivered in Latin, and formal religious education was still in many places decades or centuries away. Understanding of this basic theology then may in fact have been new to many parishioners, who hitherto had not understood the mysteries of Christianity, although we have no way of knowing for sure.

Here we see that many of Luther's songs had a clear role to play in the ritual culture of Christianity. There were songs designed for the holidays, and then there were the songs designed for everyday use in the liturgy. External to these liturgical songs, we also have a third category: Luther's musical catechism. If we divide Luther's small catechism into its six principal parts, we see that Luther prepared a simple and eloquent versification of each:

Small Catechism (1529)

Part 1: The Ten Commandments

44 Ibid., 248.

45 LW 53:256-7 


\section{Adam Hough}

Part 2: The Creed

Part 3: The Lord's Prayer

Part 4: Baptism

Part 5: Confession and Absolution

Part 6: Sacrament of the Altar

Luther's Hymns

(1524) "These are the Holy Ten Commandments" ${ }_{46}$

(1524) "In One True God We All Believe"

(1539) "Our Father in the Heaven Who Art"

(1541) "To Jordan When Our Lord Had Gone"

(1523) "From Deep Trouble I Cry To Thee"47

(1524) "Jesus Christ, Our God and Saviour"

Excepting his hymns on baptism and the Lord's Prayer, we see that Luther was clearly invested in the development of an intelligible catechism for the young and uneducated early in his career as a reformer. While there was certainly some functional overlap in the previously mentioned songs, as with "From Deep Trouble", they clearly had an educational function. These songs essentially provide the core of Luther's small catechism. The problem with classifying these songs as 'educational', however, is that it implies that his other songs were not, which is certainly not the case. Again, as these songs here correspond to the articles of Luther's small catechism, we can label them 'catechistic'; this, however, perhaps misrepresents Luther's traditional understanding and usage of the word 'catechism'. As Luther defines it,

46 While in this hymn Luther allows a stanza for each commandment, along with an introductory and concluding stanza, he also wrote a much shorter five stanza hymn on the Decalogue, "Man, Wouldst Thou live All Blissfully." Ibid., 281.

47 In Leupold's organization of the hymns in their topical and liturgical parts, he makes no mention of confession and absolution or its musical counterpart in his catechism sub-section. In the original edition of the Small Catechism, Luther did not clearly articulate confession and absolution as one of the sacraments, though he would later. My pairing of "From Deep Trouble I Cry to Thee" with this sacrament is based on Robin Leaver's analysis of the hymn. Paraphrasing Luther, he writes, "The Commandments must be allowed to condemn the sinner, and the confessor should pronounce God's promise of forgiveness and declare God's Word from Scripture. (...) All this is paralleled in Luther's Aus tiefer Not." Leaver, 151. 


\section{Martin Luther and Musically \\ Expressed Theology}

"Catechism means the instruction in which the heathens who want to be Christians are taught and guided in what they should believe, know, do, and leave undone, according to the Christian faith." ${ }^{48}$ The three most important elements of this education should be the Ten Commandments, the Creed, and the Our Father. "These three," he writes, "plainly and briefly contain everything that a Christian needs to know." ${ }^{\prime 9}$ Luther understood catechism as a basic understanding of the core tenets of Christianity. With respect to its instruction, he cautioned that learning the catechism must not be a passive activity. Pupils ought to not only understand these articles, but also be able to explain and articulate these beliefs to others. Children had to be prepared thusly so that one day they could instruct their own children properly. Luther stresses, however, that it was not enough for students to simply learn the words by rote. It was the meaning that mattered. Where Luther writes that the basic catechism contains everything a Christian needs to know, acquisition of that knowledge presupposes spiritual understanding. In this context, we have to consider his catechism hymns as a part of Luther's musically expressed theological education, and not the whole.

It is to this purpose that we now turn to the fourth category of Luther's hymns. Leupold titles his final category of Luther's songs as 'The Gospel of the Reformation'. A number of these songs seem to have been written by Luther as a response to current events of great import. The first of these, for example, "A New Song Shall Be Begun", is a lengthy narrative of the martyrdom of two reformed Augustinian monks in Holland. Rather than lamenting their deaths, Luther celebrates their conviction and heralds their deaths as Christian victories. "Oh! they sang sweet, and they sang sour;/ Oh! they tried every double'/ The boys they stood firm as a tower" ${ }^{50}$ Shortly after

\section{$4853: 64$}

49 Ibid., 65 Given this emphasis on the Decalogue, the Creed, and the Lord's Prayer, it seems unusual that Luther waited so long to write his hymn on the Lord's prayer. It could be the case, as Leaver argues, that because there were already quite a few musical renditions of the Prayer in the vernacular as early as the 1520 's, Luther did not feel pressured to write his own. (Leaver , 128-34). In the case of "Were God Not With Us At This Time" though, Luther wrote his own versification of Psalm 120 knowing full well that Spalatin had produced a vernacular version of the hymn only months before. See $L W$ 53: 245-6.

50 LW 53:214-6. 
he writes this song, Luther writes a second hymn following the same theme, that God's hand could once again be seen in unfolding events. In this song, "Dear Christians, Let Us Now Rejoice," Luther reflects on the circumstances of his own conversion. As with "From Deep Trouble I Cry To Thee", this is a deeply personal hymn. Luther writes, "Forlorn and lost in death lay I,/ A captive to the Devil." ${ }^{51}$ Ultimately though, the song tells how God sent Christ to relieve Luther of his burdens so that he might spread God's kingdom. It seems appropriate then to categorize these songs as Gospel- the "good news" of the Reformation. The third song in this set, "Ah God, from Heaven Look Down" likewise evidences a great deal of Luther's confidence in the evangelical movement. This song, in fact, is a clear attack on Catholicism. He writes, "They teach a cunning false and fine;" and later "And let us dwell in thee, secure/ From error's infiltration./ The godless rout is all around/ Where these rude wanton ones are found/ Against thy folk exalted." ${ }^{2}$

The final two songs here though, "Our God He Is a Castle Strong" and "Lord Keep Us Steadfast in Thy Word" betray Luther's early confidence. The former, written probably around $1527 / 8,{ }^{53}$ seems to suggest that the evangelicals' victory will no longer be on earth, as he had earlier forecasted, but will be in the afterlife. "If they take our life,/ Wealth, name, child and wife-/ Let everything go:/ They have no profit so;/ The kingdom ours remaineth." ${ }^{54}$ Similarly, "Lord Keep Us Steadfast" is a petition to God for help in staving off Christendom's enemies, the Pope and the 'Turk'. As Leupold suggests, this song was likely a reaction to a series of Ottoman victories over the Empire in both the Balkans and the Mediterranean. The song ends, "Stand by us breathing our last breath,/ Lead us to life straight out of death." 55

At first glance, these five hymns do not seem to fit comfortably into any of the previous categories. In fact, given their content and tone, one might be reasonably tempted to approach them not as Gospel, but as evangelical polemic. The texts of these songs, for example, reveal the 'otherness' of Catholicism with respect to Christianity. Whether

51 Ibid., 219.

52 Ibid., 227-8.

53 See Leupold's introduction to the song for more on its dating. Ibid., 283-4.

54 Ibid., 284-5.

55 Ibid., 305. 


\section{Martin Luther and Musically \\ Expressed Theology}

they describe Lutheran victories over persecution and false doctrine, or else call for militant resolve and determination against seemingly overwhelming adversity, these particular songs seem to reinforce Lutheran conviction and identity as antithetical to their Catholic counterpart.

While it is important to acknowledge the polemical character of these hymns, we must not ignore the explicitly theological nature of even these songs. At the heart of each we find the doctrine of justification and its promise of salvation through faith. All five present this central tenet in the context of great trial and tribulation. As Luther taught, understanding of the Word required a form of spiritual awakening, which typically came about as a reaction to a profoundly emotional and spiritual experience. In his case, Luther was brought closer to God through a series of near-death experiences. In pairing the affective poignancy of music with the trials that faced the Lutheran community, Luther thought to reproduce that catalytic experience in those who sang these hymns. The message in each case is simple but powerful: in times of trouble, put your faith in Christ and the Word of God and everything will be fine. In this sense, these songs can justifiably be understood as an expression and extension of the Gospel.

In all, Luther wrote over forty songs. By 1524 he had already written two thirds of these, and by 1529 three quarters. Before Luther ever put pen to paper to write his catechisms, Lutheran theology was already being taught to the young and to the uneducated, illiterate peasants through song. In the church service, Luther's hymns uncovered the mystery behind the liturgical expressions of Christian worship. In times of communal celebration, his hymns exhorted celebrants to recognize the hand of God in all things good and holy. In times of mourning, there were songs that comforted the heartsick with the reminder that it was a benevolent God to whom their loved ones departed. In a schoolboy's education, readings from scripture were prefaced, summarized, and analyzed through song. In the Sunday service for the laity, the theological lesson of the day's sermon was likewise intended to be framed and made intelligible through the accompaniment and singing of hymns. Finally, in the public sphere as elsewhere, Luther's 'Gospel' hymns were a constant reminder to keep the doctrine of justification close at all times like a shield or armour. No matter what transpired on earth, faith in God was the surest defence. 


\section{Bibliography}

\section{Primary Sources}

WA, Luther, Martin. D. Martin Luther's Werke: Kritische

Gesamtausgabe. Weimar: Hermann Böhlaus Nachfolger, 18831997.

Tischreden (TR) D. Martin Luther's Tischreden oder Colloquia, so er in vielen Jahren gegen gelahrten Leuten, auch fremden Gästen und seinen Tischgesellen geführet, nach den Hauptstücken unserer christlichen Lehre zusammen getragen, 1531-1546. (Volume supp. 02 pt. 1-6) 1846-8.

Briefe (Br) Dr. Martin Luther's Saemmtliche Schriften, band 21, "Briefe" Teil 2 von 1533 bis 1546 incl., von Joh. Georg Walch.

LW, Luther, Martin. Luther's Works. American Edition. eds. Jaroslav Pelican and Helmut T. Lehmann. 55 Volumes. St. Louis: Concordia Publishing House; Philadelphia: Fortress Press, 1955-1986.

Augustine. Confessions, 10:33.

The Book of Concord: Confessions of the Evangelical Lutheran Church. eds. Robert Kolb and Timothy J., Wengert; trans. Charles Arand...[et al.]. Minneapolis: Augsburg Fortress, 2000.

The Book of Concord: Confessions of the Evangelical Lutheran Church. ed. trans. Theodore G. Tappert, with Jaroslav Pelikan, Robert H. Fischer, and Arthur C. Piepkorn. Philadelphia: Fortress Press, 1959.

\section{Secondary Sources}

Oxford Encyclopedia of the Reformation. ed. Hans J. Hillerbrand.

Oxford University Press, 1996, 2005 (e-reference

edition). http://dx.doi.org/10.1093/acref/9780195064933.001.0001 


\section{Martin Luther and Musically \\ Expressed Theology}

The Cambridge Companion to Martin Luther. ed. Donald. K. McKim, Cambridge: Cambridge University Press, 2003. http://dx.doi.org/10.1017/ccol0521816483

Bartel, Dietrich. Musica Poetica: Musical-Rhetorical Figures in German Baroque Music. University of Nebraska Press, 1997.

Boyd-Brown, Christopher. Singing the Gospel: Lutheran Hymns and the Success of the Reformation. Cambridge: Harvard University Press, 2005. http://dx.doi.org/10.4159/9780674028913

Brecht, Martin. Martin Luther. trans. James L. Schaaf. Vols. 1 and 2. Philadelphia: Fortress Press, 1985-1993.

Burke, Peter. Popular Culture in Early Modern Europe. $3^{\text {rd }}$ Ed. Burlington: Ashgate, 2009.

Herl, Joseph. Worship Wars in Early Lutheranism: Choir, Congregation, and Three Centuries of Conflict. New York: Oxford University Press, 2004 http://dx.doi.org/10.1093/acprof:oso/9780195365849.001.0001

Kolb, Robert. Martin Luther: Confessor of the Faith. New York: Oxford University Press, 2009.

http://dx.doi.org/10.1093/acprof:oso/9780199208937.001.0001

Leaver, Robin. "Lutheran Vespers as a Context for Music," in Church, Stage, and Studio: Music and its Contexts in Seventeenth-Century Germany, ed. Paul Walker. Studies in Music, no. 107. Ann Arbor: UMI Research Press, 1990, 143-161.

Leaver, Robin. Luther's Liturgical Music: Principles and Implications.

Grand Rapids: William B. Eerdmans Pub. House, 2007.

Wengert, Timothy J. "Review: The Cambridge Luther, an Unreliable Companion," Lutheran Quarterly. Vol. 19 (2005): 79-84. 